\title{
Surgery despite multiple non-interventional images of a porcelain aorta
}

\author{
Farhana Ara (10,1,2 Ali Bara Ahmed Kamel Al-Hadithi, ${ }^{2}$ Momin Alizadeh ${ }^{3}$
}

${ }^{1}$ Cardiology, East and North Hertfordshire NHS Trust, Stevenage, UK ${ }^{2}$ Cardiology, Royal Papworth Hospital NHS Foundation Trust, Cambridge, UK

${ }^{3}$ Cardiology, Whipps Cross University Hospital NHS Trust, London, UK

\section{Correspondence to} Dr Farhana Ara;

FarhanaAra@nhs.net

Accepted 28 April 2020

\section{DESCRIPTION}

An 80-year-old woman with coronary artery disease, mitral regurgitation and persistent atrial fibrillation with intermittent rapid ventricular rate was accepted for Coronary Artery Bypass Grafting $(\mathrm{CABG})$ with epicardial lead insertion, at a joint CTS-cardiology meeting.

A porcelain aorta was found following the midline sternotomy incision and the patient was deemed unsuitable for surgery. Retrospective review of her imaging showed a heavily calcified aorta on electrophysiology fluoroscopy (figure 1) and other radiographic studies (figure 2 ), potentially precluding a surgical option.

Preoperative identification of a porcelain aorta is critical. Extensive circumferential aortic calcification has important clinical implications for cardiac surgery. ${ }^{1}$ Severe aortic atherosclerosis usually suggests systemic atherosclerosis, increasing the risk of perioperative complications including stroke. ${ }^{2} \mathrm{~A}$ porcelain aorta is technically problematic for aortic clamping, aortotomy and central coronary bypass anastomosis. ${ }^{3}$ Overall, a porcelain aorta is associated with increased morbidity and mortality. ${ }^{3}$

Diagnosis of a porcelain aorta is often incidental, or as part of dedicated screening, in the evaluation of an embolic event or in procedural planning. ${ }^{4}$ Clinicians must be attentive to recognising this condition, which may be identified on chest X-ray, fluoroscopy, angiographic and echocardiographic imaging. Further assessment can then be performed

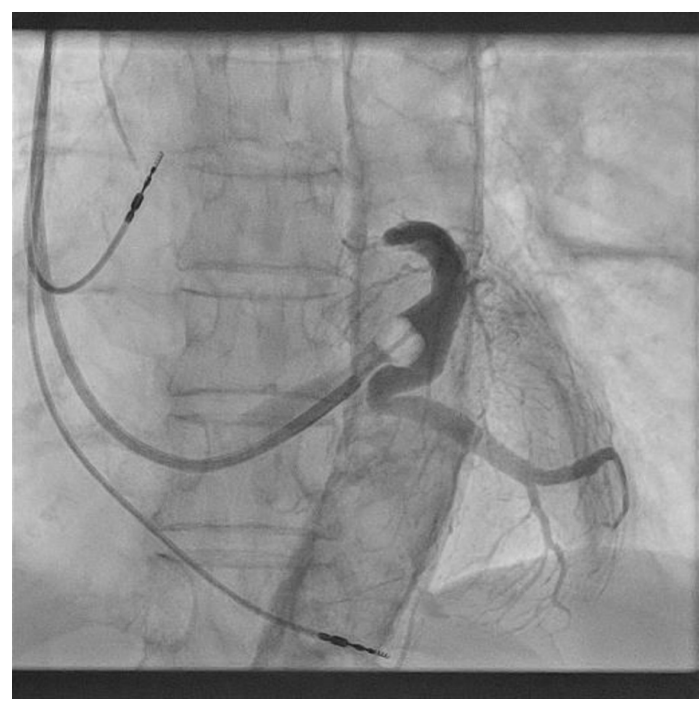

Figure 1 Fluoroscopy during attempted Cardiac Resynchronisation Therapy (CRT) upgrade shows a heavily calcified aorta.

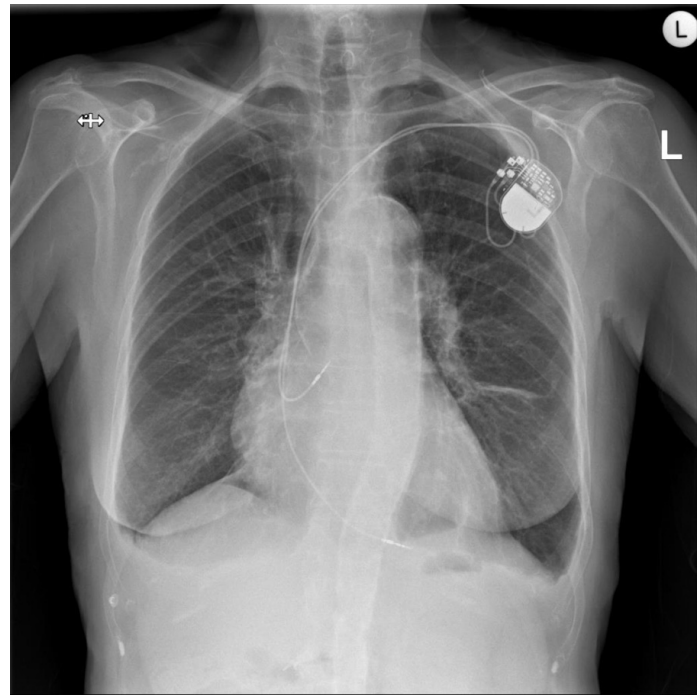

Figure 2 Chest X-ray prior to admission to the operating theatre shows a porcelain aorta.

using non-contrast CT, to assess burden of calcification $^{5}$ as well as electron-beam CT and multislice (spiral) CT for cardiac, coronary and aortic calcification. ${ }^{6}$ Comprehensive preprocedural imaging allows for planning of alternative management strategies including hybrid off-pump CABG surgery and transcatheter approaches.

This case raises an ethical dilemma. The patient could potentially have avoided a trip to the operating theatre and a midline sternotomy scar. However, it is well established that palpation during open heart surgery is not an uncommon presentation of a porcelain aorta and that the most sensitive technique for detecting ascending aortic atheroma and calcification during open heart surgery is epiaortic echocardiographic scanning of the aorta in conjunction with manual palpation. ${ }^{8}$

It has also been recently reported that novel surgical approaches including simultaneous transapical transcatheter aortic and mitral valve implantation, may be considered in the future for patients diagnosed with a porcelain aorta with an indication for surgery. ${ }^{9}$

\section{Learning points}

Clinicians must be attentive to diagnosing a porcelain aorta, which can be identified on various imaging modalities.

- Diagnosing a porcelain aorta has wide-ranging implications for surgical intervention, but this needs multidisciplinary discussion and preplanning. 
On review of the case, the risks of proceeding with further investigations and intervention were discussed with the patient. The decision was made not to pursue any further treatment and the patient was discharged to a residential home. The patient has been doing well since discharge.

Twitter Farhana Ara @FarhanaAra

Acknowledgements With thanks to Dr M Virdee, consultant cardiologist at Royal Papworth Hospital.

Contributors FA is the guarantor of submission. FA and ABAKA-H were responsible for collecting the data and drafting the case report. MA researched the material, performed a literature search and revised the draft. All parties are happy to be accountable for all aspects of the work and give final approval for the work to be published.

Funding The authors have not declared a specific grant for this research from any funding agency in the public, commercial or not-for-profit sectors.

Competing interests None declared.

Patient consent for publication Obtained.

Provenance and peer review Not commissioned; externally peer reviewed.

ORCID iD

Farhana Ara http://orcid.org/0000-0002-3799-7743

\section{REFERENCES}

1 van der Linden J, Hadjinikolaou L, Bergman P, et al. Postoperative stroke in cardiac surgery is related to the location and extent of atherosclerotic disease in the ascending aorta. J Am Coll Cardiol 2001;38:131-5.

2 Fukuda I, Daitoku K, Minakawa M, et al. Shaggy and calcified aorta: surgical implications. Gen Thorac Cardiovasc Surg 2013;61:301-13.

3 Abramowitz $\mathrm{Y}$, Jilaihawi $\mathrm{H}$, Chakravarty $\mathrm{T}$, et al. Porcelain aorta: a comprehensive review. Circulation 2015;131:827-36.

4 Desai MY, Cremer PC, Schoenhagen P. Thoracic aortic calcification: diagnostic, prognostic, and management considerations. JACC Cardiovasc Imaging 2018;11:1012-26

5 Adesanya TMA, Kilic A. Dealing with a porcelain aorta during coronary artery bypass grafting. Case Rep Surg 2014;2014:1-4.

6 Eisen A, Tenenbaum A, Koren-Morag N, et al. Calcification of the thoracic aorta as detected by spiral computed tomography among stable angina pectoris patients: association with cardiovascular events and death. Circulation 2008;118:1328-34.

7 Baquero GA, Azarrafiy R, de Marchena EJ, et al. Hybrid off-pump coronary artery bypass grafting surgery and transaortic transcatheter aortic valve replacement: literature review of a feasible bailout for patients with complex coronary anatomy and poor femoral access. J Card Surg 2019;34:591-7.

8 Sylivris S, Calafiore P, Matalanis G, et al. The intraoperative assessment of ascending aortic atheroma: epiaortic imaging is superior to both transesophageal echocardiography and direct palpation. J Cardiothorac Vasc Anesth 1997:11:704-7.

9 Belhaj Soulami R, Anselmi A, Leurent G, et al. Simultaneous transapical aortic and mitral valve implantation in a patient with porcelain aorta. Eur J Cardiothorac Surg 2019:56:1202-3.

Copyright 2020 BMJ Publishing Group. All rights reserved. For permission to reuse any of this content visit

https://www.bmj.com/company/products-services/rights-and-licensing/permissions/

BMJ Case Report Fellows may re-use this article for personal use and teaching without any further permission.

Become a Fellow of BMJ Case Reports today and you can:

- Submit as many cases as you like

- Enjoy fast sympathetic peer review and rapid publication of accepted articles

- Access all the published articles

- Re-use any of the published material for personal use and teaching without further permission

\section{Customer Service}

If you have any further queries about your subscription, please contact our customer services team on +44 (0) 2071111105 or via email at support@bmj.com.

Visit casereports.bmj.com for more articles like this and to become a Fellow 